\title{
Metabolic fuel selection by intestinal epithelium
}

\author{
BY JEHAN-FRANÇOIS DESJEUX \\ Conservatoire National des Arts et Métiers and INSERM U.290, Hôpital Saint-Lazare, \\ 107 rue du Faubourg, Saint-Denis, 75010 Paris, France
}

\section{Sélection des substrats énergétique par l'épithélium intestinal}

\begin{abstract}
RÉSUMÉ
Les nutriments présents dans la lumière intestinale après un repas sont absorbés sélectivement par l'épithélium intestinal. L'absorption varie avec le mode d'alimentation et avec les conditions physiologiques (croissance, lactation, vieillissement) et avec les conditions pathologiques liées ou non à la nutrition. En principe, ces variations d'absorption pourraient s'expliquer, au moins en partie, par des variations du passage sélectif de substrats à travers l'épithélium intestinal. Cette sélectivité est due à la présence de transporteurs qui sont membranaires pour les substances hydrosolubles et intracellulaires pour les substances liposolubles. Les cellules épithéliales sont caractérisées par une asymétrie de composition membranaire que l'on retrouve au niveau des transporteurs. Cette asymétrie de composition permet d'expliquer le transport vectoriel de la lumière intestinale vers le sang. Comme ces transporteurs sélectifs sont des protéines, il n'est pas étonnant de constater que leur expression est sous contrôle génétique et métabolique. Bien que le rôle de ces transporteurs dans les variations de l'absorption soit encore peu étudié, certains exemples tirés de la physiologie (modification de la composition alimentaire) et de la pathologie (diabète) montrent clairement que la régulation de l'expression des transporteurs membranaires peut participer au contrôle de la sélection des substrats énergétiques au moment de l'absorption.
\end{abstract}

Nutrients present in the intestinal lumen are selectively absorbed by the intestinal epithelium. The concept of selectivity reflects the concept of a barrier and has been extensively studied by biophysicists, biochemists, and geneticists (Powell, 1994). Recently, the three strategies have been merged into one integrated concept that could be useful to nutritionists. This development can be traced back to 1986 when chloride selective conductance through the luminal membrane of epithelial cells was found to be supported by transmembrane protein having phosphorylation sites under the genetic control of a gene called CFTR (Frizzell et al. 1986; Collins et al. 1987; Drumm et al. 1991).

In bacteria, the cytoplasmic membrane is the structure that selects nutrients required for growth and reproduction. The genetic control of transmembrane transport proteins is essential for bacteria to grow in their environment. In mammals, the intestinal epithelium shows some resemblance to the bacterial membrane but has a higher degree of complexity: (1) each cell is surrounded by a luminal membrane and a basolateral 
membrane; both membrane domains differing in structure and function. In addition, the intestinal epithelium is a monolayer of epithelial cells attached by a specific structure called zonula occludens. This epithelial asymmetric structure is the support for vectorial transport; (2) the intestinal epithelium not only covers the entire surface of the intestinal lumen but is continuously renewed; i.e. the epithelial function is surface-and-timedependent; (3) the environment of the intestinal epithelium comprises the luminal content, the composition of which keeps changing with time, and somatic systems on the serosal side, including endocrine, nerve, immune and vascular systems in the subepithelial space.

Intestinal nutrient absorption is subject to variation (1) associated with feeding, including feeding pattern, diet composition, route of administration (enteral $v$. parenteral feeding), (2) with physiological conditions, including genetic constitution, ontogeny, growth, lactation, ageing and (3) with pathological conditions including malnutrition, diabetes mellitus, ileal resection, abdominal irradiation, sepsis, intestinal infection (Gardiner \& Barbul, 1993; Thomson et al. 1994). The mechanisms involved in the alteration of intestinal absorption, which may be regarded as an adaptable response, include alterations in morphology, membrane and intracellular composition of enterocytes, cell kinetics, digestive enzyme activities and endocrine, nerve, immune and vascular system functions.

My aim is to present our current knowledge on the selection of metabolic substrates by the intestinal epithelium. Selectivity across the intestinal epithelium is achieved by specific transporters that are under genetic and metabolic control.

\section{TRANSPORTERS AND SELECTIVE PERMEABILITY ACROSS THE INTESTINAL EPITHELIUM}

At the luminal membrane of the enterocytes, the nutrients are in the form of monosaccharides, amino acids or small peptides, monoacylglycerols and free fatty acids. Water-soluble substrates are transported across lipidic membranes by transmembrane transporters, while lipid-soluble substrates require transporters to migrate within the cell.

\section{The transport of water-soluble substrates}

Monosaccharides and amino acids are absorbed into the body by the mature enterocytes lining the upper villi of the small intestine. Absorption occurs by a two-stage process: glucose and galactose are co-transported with $\mathrm{Na}^{+}$from the gut lumen into the enterocytes across the brush-border membrane by co-transporter SGLT1, followed by facilitated transport out of the cell by transporter GLUT2 (Wright et al. 1988).

Other transporters with substrate specificity have recently been identified: SAAT1 is a mammalian $\mathrm{Na}^{+}$-dependent neutral amino acid transporter identified as a protein of 90 KDa with properties characteristic of system A, i.e. transporting alanine (Kong et al. 1993). A Na ${ }^{+}$-dependent neutral L- $\alpha$-amino-acid transporter characteristic of system $B$ has been described (Nakanishi et al. 1994). Pep T1 may be a major mechanism for absorption of the products of protein digestion; it is a proton-coupled organic solute transporter (Fei et al. 1994). GLUT5 is a $\mathrm{Na}^{+}$-independent transporter for fructose and, to a lesser degree, glucose at the luminal membrane (Burant et al. 1994). 
At the basolateral membrane, GLUT2 is a $\mathrm{Na}^{+}$-independent transporter for glucose, galactose and fructose (Burant et al. 1994), but no comparable transporter for amino acids has been identified. MCT1 is a monocarboxylate transporter at the basolateral membrane. Its main function may be to export lactate from epithelial cells (Garcia et al. 1994).

Other water-soluble transporters have been identified with undefined nutritional function. NBAT is a Na-independent neutral and basic amino acid transporter. It is located on the luminal membrane of the enterocyte and, probably in greater quantity, within enteroendocrine cells and submucosal neurons (Pickel et al. 1993). Another transporter (NAA-Tr) with Na-independent amino transport properties has been identified (Yan et al. 1992).

In addition, the presence of a common carrier or multichannel transporter for glucose and amino acids suggested by Alvardo (1966) has not been established (Metel'skiol, 1992). To be functional, transporters may be in the form of hetero-oligomers. For example, mammalian $\mathrm{Na}^{+}$-D-glucose co-transport systems are hetero-oligomers containing two SGLT1-type and one or two RS1-type subunits (Koepsell \& Spangenberg, 1994). Different combinations of SGLT1-type subunits and RS1-type subunits may form the heterogeneous $\mathrm{Na}^{+}-\mathrm{D}$-glucose co-transport systems in kidney and intestine. In the same line, it is possible that the $\mathrm{D}_{2}$ molecule is part of a larger system involved in the transport of cystine and other amino acids (Kanai \& Hediger, 1992).

\section{The transport of lipid-soluble substrates}

Dietary triacylglycerols are hydrolysed in the intestine by lipases to fatty acids and monoacylglycerols which are re-esterified to form triacylglycerols in enterocytes. Triacylglycerols are assembled in the endoplasmic reticulum with other lipids and proteins to form the core of nascent chylomicrons. Dietary cholesterol also is largely esterified in these cells and incorporated into the core of the particles. After assembly in the Golgi apparatus is completed, nascent chylomicrons are secreted into the interstitium of intestinal villi and enter the lacteals. The protein components of the nascent chylomicrons are synthesized in the enterocytes and include Apo B-48 and the A apoproteins (A-I, A-II, A-IV; Havel \& Kane, 1989).

The B-apoproteins are the products of a single gene. The larger form produced by the liver, designated apo B-100 (' 100 ' represents $100 \%$ of the gene product), is a major component of VLDL and LDL and contains a binding domain for the LDL receptor. The smaller form, apo B-48, is found in chylomicrons of intestinal origin. Both apo B-48 and apo B-100 are translated from the same messenger RNA sequence, with the tissue-specific post-transcriptional or co-transcriptional insertion of a stop-codon limiting translation to apo B-48 synthesis in the intestine.

Fatty acid-binding proteins (FABP) are abundant cytosolic proteins whose level is responsive to nutritional and endocrine conditions and to a variety of pathological states. They may have a role in fatty acid and cholesterol absorption (Schroeder et al. 1993).

\section{METABOLIC FUEL SELECTION IS UNDER GENETIC CONTROL}

Most of our information on this subject comes from human congenital and selective transport defects (for recent review, see Desjeux, 1993). These rare diseases involve 
most nutrients including energy substrates and the vitamins and minerals required for their metabolism. Clinical features vary according to the nature of the substrate whose selective absorption by the intestine is impaired. The severity of the disease is an indication that the substrate is essential. The genetic defect for water-soluble substrate absorption may be at the luminal or basolateral membrane of the enterocyte. The most studied genetic transport defect of the luminal membrane is glucose-galactose malabsorption (GGM). The main symptom is neonatal diarrhoea which is relieved by a glucose- and galactose-free diet. No significant glucose metabolism dysfunction is observed. It is characterized by functional deficiency of glucose- $\mathrm{Na}^{+}$co-transporter, even though the protein is present in the membrane. A wide variety of mutations have been identified including point mutations which alter residues conserved among other $\mathrm{Na}^{+}$co-transporters (Martin et al. 1994; Turk et al. 1994). Another example of a genetic defect of transport is lysinuric protein intolerance (LPI). In this defect in selective transport of lysine and other dibasic amino acids there are severe metabolic consequences including postprandial hyperammonaemia and growth retardation. In vivo, malabsorption of the three amino acids, lysine, arginine and ornithine, given as free amino acids or dipetides, by the small intestine and the kidney (Simell, 1989) and plasma concentrations of dibasic amino acids are low. In vitro, entry of the amino acids across the luminal membrane of the epithelial cells is not impaired but the exit permeability across the basolateral membrane to the blood is grossly impaired (Desjeux et al. 1980). In addition, the transport defect is also found in other plasma membranes (fibroblast, hepatocyte). Gene coding for lysine transport across the plasma membrane has not been identified.

These examples show the importance of the genetic control of substrate selectivity by the enterocyte. In addition, they indicate that genetic control at the basolateral membrane is a limiting step in amino acid absorption.

Similarly, the study of fat malabsorption related to altered secretion of B-apoproteincontaining lipoprotein may provide information on the genetic control of fatty acid absorption. However, the findings have not been very informative. The molecular basis of abetalipoproteinaemia is unknown. The initial belief, that impaired apo-B synthesis was responsible for this disorder, may not account for all cases and it has been challenged in the light of recent results obtained with specific and sensitive methodology (Dullaart et al. 1986; Glickman et al. 1991). These findings indicate immunologically recognizable, normal size and normally glycosylated apo B-48 and B-100 are synthesized even in abetalipoproteinaemia.

\section{METABOLIC CONTROL OF TRANSPORTERS}

Factors controlling the expression of transporters also control metabolic fuel selection by the intestinal epithelium. This is illustrated by typical examples: amongst intracellular messengers, cAMP plays an interesting role in nutrition. In caco-2 intestinal cells, stimulation of cAMP production by forskolin increases fructose uptake 2-fold, and raises GLUT5 protein and mRNA levels 5- and 7-fold respectively (Mahraoui et al. 1992). As in response to hypoglycaemia, adrenaline and glucagon stimulate cAMP production, the increased fructose absorption may be part of the hypoglycaemic response (Cryer, 1993).

Extracellular molecules also participate in the control of nutrient absorption. Epidermal growth factor (EGF) which stimulates cell replication and increases the DNA 
content of the small intestine, also stimulates $\mathrm{Na}^{+}$-dependent glutamine and alanine uptake by the brush-border membrane vesicles of enterocytes. This effect is not observed for glucose (Salloum et al. 1993).

In sepsis intestinal absorption may be reduced. Recently, it has been suggested that the release of cytokines induced by systemic bacteria or endotoxin may lead to reduction in the synthesis of transporter proteins (Salloum et al. 1991; Gardiner \& Barbul, 1993).

Nutrients may also be involved in the control of transporters. Fructose in the intestinal lumen may upregulate GLUT2 expression (Cheeseman, 1992). Regulation of cholesterol uptake by enterocytes has recently been studied by Safonova et al. (1994). They found that loading the cells with non-lipoprotein-cholesterol reduced cholesterol uptake, while treatment of cells with an inhibitor of cholesterol synthesis had the opposite effect (Schroeder et al. 1993). Carbohydrate-rich diets stimulate $\mathrm{Na}^{+}-\mathrm{D}$-glucose co-transporter activity, phloridzin binding and the amount of SGLT1-homologous mRNA. This upregulation is post-transcriptional since it is correlated with the concentration of SGLT1-homologous mRNA. Post-transcriptional regulation may be due to chemical modification of SGLT1 which may alter membrane insertion or protein turnover, or may be mediated by the RS1 component (Shirazi-Beechey et al. 1991; Ferraris \& Diamond, 1992; Koepsell \& Spangenberg, 1994).

\section{WHAT IS THE ROLE OF GENETIC CONTROL OF METABOLIC FUEL SELECTION BY INTESTINAL EPITHELIUM?}

As mentioned in the introduction, nutrient absorption is altered in many physiological and pathological conditions. Glucose absorption is increased in experimentally streptozotocin-induced diabetes in rats. In the meantime, SGLT1, GLUT5 and GLUT2 are increased (Burant et al. 1994). Insulin reverses the increase in transporter-protein expression seen after induction of diabetes. In situ hybridization shows that after the induction of diabetes there is new hybridization in lower villus and crypt enterocytes. Thus, the increase in total hexose transport caused by diabetes is due to premature expression of hexose transporters by enterocytes along the crypt-villus axis, causing a cumulative increase in enterocyte transporter protein during maturation. These changes are likely to represent an adaptable response by the organism to increase nutrient absorption in a perceived state of tissue starvation, including starvation, lactation, hypophysectomy and unbalanced insulin-dependent diabetes.

In conclusion, results obtained in physiological (change in diet composition) and pathological conditions (diabetes) clearly indicate that the level of expression of specific transporters may participate in the control of metabolic fuel selection at the time of absorption.

\section{REFERENCES}

Alvarado, F. (1966). Transport of sugars and amino acids in the intestine: evidence for a common carrier. Science 151, 1010-1013.

Burant, C. F., Flink, S., Depaoli, A. M., Chen, J., Lee, W. S., Hediger, M. A., Buse, J. B. \& Chang, E. B. (1994). Small intestine hexose transport in experimental diabetes. Increased transporter mRNA and protein expression in enterocytes. Journal of Clinical Investigation 93, 578-585.

Burant, C. F., Takeda, J., Brot-Laroche, E., Bell, G. I. \& Davidson, N. O. (1992). Fructose transporter in human spermatozoa and small intestine is GLUT5. Journal of Biological Chemistry 267, 14523-14526. 
Cheeseman, C. (1992). Role of intestinal basolateral membrane in absorption of nutrients. American Journal of Physiology 263, R482-R488.

Collins, F. S., Drumm, M. L., Cole, J. L., Lockwood, W. K., Vande Woude, G. F. \& Iannuzzi, M. C. (1987). Construction of a general human chromosome jumping library, with application to cystic fibrosis. Science 235, 1046-1049.

Cryer, P. E. (1993). Glucose counterregulation: prevention and correction of hypoglycemia in humans. American Journal of Physiology 264, E149-E155.

Desjeux, J. F. (1993). Congenital selective defects of intestinal transport. In Management of Digestive and Liver Disorders in Infants and Children, pp. 175-203 [J. P. Buts and E. M. Sokal, editors]. Amsterdam: Elsevier.

Desjeux, J. F., Rajantie, J., Simell, O., Dumontier, A. M. \& Perheentupa, J. (1980). Lysine fluxes across the jejunal epithelium in lysinuric protein intolerance. Journal of Clinical Investigation 65, 1382-1387.

Drumm, M. L., Wilkinson, D. J., Smit, L. S., Worrell, R. T., Strong, T. V., Frizzell, R. A., Dawson, D. C. \& Collins, F. S. (1991). Chloride conductance expressed by delta F508 and other mutant CFTRs in Xenopus oocytes. Science 254, 1797-1799.

Dullaart, R. P. F., Speelberg, B., Schuurman, H. J., Milne, R. W., Havekes, L. M., Marcel, Y. L., Geuze, H. J., Hulshof, M. M. \& Erkelens, D. W. (1986). Epitopes of apolipoprotein B-100 and B-48 in both liver and intestine. Expression and evidence for local synthesis in recessive abetalipoproteinemia. Journal of Clinical Investigation 78, 1397-1404.

Fei, Y. J., Kanai, Y., Nussberger, S., Ganapathy, V., Leibach, F. H., Romero, M. F., Singh, S. K., Boron, W. F. \& Hediger, M. A. (1994). Expression cloning of a mammalian proton-coupled oligopeptide transporter. Nature 368, 563-566.

Ferraris, R. P. \& Diamond, J. (1992). Crypt-villus site of glucose transporter induction by dietary carbohydrate in mouse intestine. American Journal of Physiology 262, G1069-G1073.

Frizzell, R. A., Rechkemmer, G. \& Shoemaker, R. L. (1986). Altered regulation of airway epithelial cell chloride channels in cystic fibrosis. Science 233, 558-560.

Garcia, C. K., Goldstein, J. L., Pathak, R. K., Anderson, R. G. \& Brown, M. S. (1994). Molecular characterization of a membrane transporter for lactate, pyruvate, and other monocarboxylates: implications for the Cori cycle. Cell 76, 865-873.

Gardiner, K. \& Barbul, A. (1993). Intestinal amino acid absorption during sepsis. Journal of Parenteral and Enteral Nutrition 17, 277-283.

Glickman, R. M., Glickman, J. N., Magun, A. \& Brin, M. (1991). Apolipoprotein synthesis in normal and abetalipoproteinemic intestinal mucosa. Gastroenterology 101, 749-755.

Havel, R. J. \& Kane, J. P. (1989). Structure and metabolism of plasma lipoproteins. In The Metabolic Basis of Inherited Disease, pp. 1129-1138 [C. R. Scriver, A. L. Beaudet, W. S. Sly and D. Valle, editors]. New York: McGraw-Hill.

Kanai, Y. \& Hediger, M. A. (1992). Primary structure and functional-characterization of a high-affinity glutamate transporter. Nature $6403,467-471$.

Koepsell, H. \& Spangenberg, J. (1994). Function and presumed molecular structure of $\mathrm{Na}^{+}$-D-glucose cotransport. Journal of Membrane Biology 138, 1-11.

Kong, C. T., Yet, S. F. \& Lever, J. E. (1993). Cloning and expression of a mammalian $\mathrm{Na}^{+}$amino acid cotransporter with sequence similarity to $\mathrm{Na}^{+}$glucose cotransporters. Journal of Biological Chemistry 268, 1509-1512.

Mahraoui, L., Rousset, M., Dussaulx, E., Darmoul, D., Zweibaum, A. \& Brot-Laroche, E. (1992). Expression and localization of GLUT-5 in caco-2 cells, human small intestine, and colon. American Journal of Physiology 263, G312-G318.

Martin, M. G., Turk, E., Kahulis, C. \& Wright, E. M. (1994). Glucose-galactose malabsorption is associated with abnormalities of the $\mathrm{Na}^{+}$glucose transporter. Gastroenterology 106, A252.

Metel'skioi, S. T. (1992). A multichannel t̀ransporter for glucose and amino acid transport. Fiziologicheskii Zhurnal SSSR Imeni Im Sechenua 78, 84-92.

Nakanishi, M., Kagawa, Y., Narita, Y. \& Hirata, H. (1994). Purification and reconstitution of an intestinal $\mathrm{Na}(+)$-dependent neutral L-alpha-amino acid transporter. Journal of Biological Chemistry 269, 9325-9329.

Pickel, V. M., Nirenberg, M. J., Chan, J., Mosckovitz, R., Udenfriend, S. \& Tate, S. S. (1993). Ultrastructural localization of a neutral and basic amino acid transporter in rat kidney and intestine. Proceedings of the National Academy of Sciences, USA 90, 7779-7783.

Powell, D. W. (1994). Barrier function of epithelia. American Journal of Physiology 241, G275-G288. 
Safonova, I. G., Sviridov, D. D., Nano, J. L., Rampal, P. \& Repin, V. S. (1994). Regulation of cholesterol uptake in the rat intestinal cell line. Biochimica et Biophysica Acta 1210, 181-186.

Salloum, R. M., Copeland, E. M. \& Souba, W. W. (1991). Brush border transport of glutamine and other substrates during sepsis and endotoxemia. Annals of Surgery 213, 401-409.

Salloum, R. M., Stevens, B. R., Schultz, G. S. \& Souba, W. W. (1993). Regulation of small intestinal glutamine transport by epidermal growth factor. Surgery 113, 552-559.

Schroeder, F., Jefferson, J. R., Powell, D., Incerpi, S., Woodford, J. K., Colles, S. M., Myers-Pyne, S., Emge, T., Hubbell, T. \& Moncecchi, D. (1993). Expression of rat l-fabp in mouse fibroblasts: role in fat absorption. Molecular and Cell Biochemistry 123, 73-83.

Shirazi-Beechey, S. P., Hirayama, B. A., Wang, Y., Scott, D., Smith, M. W. \& Wright, E. M. (1991). Ontogenic development of lamb intestinal sodium-glucose co-transporter is regulated by diet. Journal of Physiology 437, 699-708.

Simell, O. (1989). Lysinuric protein intolerance and other cationic aminoaciduria. In The Metabolic Basis of Inherited Disease, pp. 2497-2513 [C. R. Scriver, A. L. Beaudet, W. S. Sly and D. Valle, editors]. New York: McGraw-Hill.

Thomson, A. B., Cheeseman, C. I., Keelan, M., Fedorak, R. \& Clandinin, M. T. (1994). Crypt cell production rate, enterocyte turnover time and appearance of transport along the jejunal villus of the rat. Biochimica et Biophysica Acta 1191, 197-204.

Turk, E., Martin, M. G. \& Wright, E. M. (1994). Structure of the human $\mathrm{Na}^{+} /$glucose cotransporter gene SGLT1. Journal of Biological Chemistry 269, 15204-15209.

Wright, E. M., Turk, E., Zabel, B., Mundlos, S. \& Dyer, J. (1991). Molecular genetics of intestinal glucose transport. Journal of Clinical Investigation 88, 1435-1440.

Yan, N., Mosckovitz, R., Udenfriend, S. \& Tate, S. S. (1992). Distribution of mRNA of a Na(+)-independent neutral amino acid transporter cloned from rat kidney and its expression in mammalian tissues and Xenopus laevis oocytes. Proceedings of the National Academy of Sciences, USA 89, 9982-9985. 